\title{
Effects of lines and inoculants on nutritive value and production costs of triticale silages
}

\author{
Ekin Sucu ${ }^{1}$, Esra Aydoğan Çifci ${ }^{2}$
}

\begin{abstract}
1 Uludag University, Faculty of Agriculture, Department of Animal Science, Bursa, Turkey.
${ }^{2}$ Uludag University, Faculty of Agriculture, Department of Crop Science, Bursa, Turkey.
\end{abstract}

\begin{abstract}
The current study was undertaken to investigate the ensilage characteristics in triticale lines treated by inoculants and their interaction on fermentation metabolites and rumen degradability. Costs were estimated for growing and feeding whole-crop triticale lines for animal production. Triticale hybrids were harvested at the dough stage of maturity $(38 \%$ dry matter, DM). Plants were chopped approximately $2 \mathrm{~cm}$ after harvest and then treated with inoculants and were ensiled in 1.5-L mini laboratory silos. Two lactic acid bacterial inoculants with enzymes (LAB+enzymes I: Pediococcus acidilactici, Lactobacillus plantarum, and Streptococcus faecium with cellulase, hemicellulase, pentosanase, and amylase; LAB+enzyme II: P. acidilactici, L. plantarum, and amylase) were used as silage additives. Inoculants were applied at $1.5 \times 10^{5} \mathrm{cfu} / \mathrm{g}$ chopped fresh material. Silages with no additive served as the control. Four jars per treatment were sampled on day 60 after ensiling for chemical and microbiological analysis. At the end of the ensiling period (60 day), the silages were subjected to an aerobic stability test. The nutrient degradability of silages was determined in situ. Overall, there were no obvious interactions between triticale lines and the treatments for any of the parameters measured. The fermentation and nutritive value of silages were affected by treatments. LAB+enzymes increased the concentrations of lactic acid of the triticale silages and decreased the concentrations of butyric acid, total alcohols, and ammonia-N. Under aerobic conditions, LAB+enzyme treated silages had lower $\mathrm{pH}, \mathrm{CO}_{2}$ production, and number of yeasts. Fibrous fractions were decreased with the application of LAB+enzymes. The $48 \mathrm{~h}$ in situ organic matter, DM, and neutral detergent fiber digestibility of the silages were enhanced by treatments. Addition $\mathrm{LAB}+$ enzymes to dough stage triticale silage reduces proteolysis; the inoculant possess antimicrobial properties and improves fermentation and nutritional value. The economic results are favorable financially for growing winter triticale as an animal feed in Mediterranean-type climates.
\end{abstract}

Key Words: cost, degradability, enzymes, fermentation, lactic acid bacteria, triticale lines

\section{Introduction}

Forage resources and their utilization will be modified in the future because of soil and climate constraints (Steenwerth et al., 2014). Triticale has been a crop of future promise. It offers several advantages including an extended growing period that is adapted well to acidic, droughty, or other extreme conditions (Kara et al., 2009; Hackett et al., 2012; Kaplan et al., 2015) with low production costs (Saade, 1995; Lozano-del Rio et al., 2004; Hackett et al., 2012). Recent advances in triticale breeding and harvesting have renewed interest in the integration of triticale as forage in animal production. This interest is particularly apparent with dairy farmers; however, triticale forage may also be suitable pasture forage for grazing beef cattle. Whole crop

Received January 4, 2016 and accepted May 11, 2016.

Corresponding author: ekins@uludag.edu.tr

http://dx.doi.org/10.1590/S1806-92902016000700001

Copyright (C) 2016 Sociedade Brasileira de Zootecnia. This is an Open Access article distributed under the terms of the Creative Commons Attribution License (http://creativecommons.org/licenses/by/4.0/), which permits unrestricted use, distribution, and reproduction in any medium, provided the original work is properly cited. triticale silage can provide a good option for dairy dry cows, heifers, and beef cattle as energy and an effective fiber source (Hogg et al., 2002; Lozano del Rio et al., 2004; Myer and Lozano del Rio, 2004; Jacobs et al., 2009).

It is very important to note that the nutritional value and ensiling process of triticale vitally depend on its maturation stage. During the dough stage of maturity, the grain is comprised of a starchy endosperm, protein, some lipid in the germ, and fiber (Kennelly and Weinberg, 2003; Lozano-del Rio et al., 2010). Harvesting in the dough stage of maturity improves the chance of avoiding rainfall during the silage-making process. Harvesting in this stage can also maximize dry matter yields. However, during the dough stage of maturity, the number of epiphytic LAB as well as the level of water soluble carbohydrates (WSC) and the degree of digestibility may not be optimal (McDonald et al., 1991). Hence, multi species bacterial inoculant and enzyme treatments could be effective in mature forages (McDonald et al., 1991; Kung et al., 2003). The potential benefits of these additives include improved silage quality as measured by a reduction of the cell wall component, increased available substrate, and higher digestibility 
(McDonald et al., 1991; Kung et al., 2003). This may lead to improved livestock performance; e.g., increased feed intake, improved feed efficiency, faster daily gain, and increased milk and milk solids production (Kung et al., 2003; Adesogan, 2005; Demirel et al., 2013).

Although there is a considerable amount of information available on the growing winter triticale as a feed source (Lozano-del Rio et al., 2004; Myer and Lozano-del Rio, 2004; Nadeau, 2007; Jacobs et al., 2009; Ozduven et al., 2010; Demirel et al., 2013), little is known about harvesting at the dough stage of maturity and the levels of performance that can be achieved when grown in the subtropics. Hence, the objective of this study was to summarize the ensilage characteristics of different triticale lines by using multi species bacterial inoculants with enzymes and their interaction on fermentation metabolites and digestibility of triticale silages harvested at the dough stage of maturity. Another goal here was to understand the feasibility of using winter triticale as an economical alternative for other forages in the Mediterranean region.

\section{Material and Methods}

The field experiment was carried out in Bursa, Turkey. The experimental station is located in the coastal zone of northwest Turkey $\left(40^{\circ} 11^{\prime} \mathrm{N}, 29^{\circ} 04^{\prime} \mathrm{E}\right), 70 \mathrm{~m}$ above sea level. This climatic zone is characterized by a Mediterraneantype climate. The soil was a clay loam, classified as vertisol typic habloxrert, slightly alkaline ( $\mathrm{pH}$ is 7.2$)$, medium in $\mathrm{P}(73 \mathrm{~kg} / \mathrm{ha})$, rich in $\mathrm{K}(1130 \mathrm{~kg} / \mathrm{ha})$, and containing $1.4 \%$ organic matter. Four CIMMYT (International Maize and Wheat Improvement Center) winter triticale lines, randomly selected out of 33 triticale lines from yield trial, were evaluated for forage production in this study (Table 1).

The plot size was $6.0 \mathrm{~m}^{2}(5 \mathrm{~m} \times 1.2 \mathrm{~m})$, consisting of eight rows spaced at $15.0 \mathrm{~cm}$. Seeds were planted using a plot drill with 550 seeds $/ \mathrm{m}^{2}$ graining rate. The basic preplanting fertilization rates for all plots were $\mathrm{N} 50$ and $\mathrm{P}$ $50 \mathrm{~kg} / \mathrm{ha}$, with $\mathrm{N}$ top-dressing of $100 \mathrm{~kg} / \mathrm{ha}$. Irrigation was not performed and herbicide was used for broad-leaf and narrow-leaf weeds

Forage was harvested when each line reached the dough stage in June. Forage samples were harvested from a $1.2 \mathrm{~m}^{2}$ center area of each plot to measure forage yields. A total of $500 \mathrm{~g}$ fresh sample were taken from harvested plants and dried at $70{ }^{\circ} \mathrm{C}$ for $48 \mathrm{~h}$. Then, hay yields were determined. Prior to harvest, plant height was measured from the base of the plant to the top of the spike excluding the awns in 10 randomly selected plants. Plant samples from each line were cut at ground-level and separated into leaf, spike, and stalk. These components were individually dried and weighed.

Four triticale lines were harvested by hand at the dough stage and chopped with a laboratory-type chopper (Fimaks, Turkey) to about $2.0 \mathrm{~cm}$. Within $1 \mathrm{~h}$ of chopping, the following treatments were applied to fresh forage: a control (no additive); LAB+enzymes I (Pediococcus acidilactici, Lactobacillus plantarum, and Streptococcus faecium with cellulase, hemicellulase, pentosanase, and amylase); and LAB+enzyme II ( $P$. acidilactici, L. plantarum, and amylase). Inoculants $(1.5 \mathrm{~g})$ were suspended in $100 \mathrm{~mL}$ of tap water and the whole suspension was sprayed over $10 \mathrm{~kg}$ (wet weight) of the chopped forage spread over a $1 \times 4 \mathrm{~m}$ area. The control was sprayed with the same amount of water and no additives. The amount of chopped forage for a given jar was weighed out, sprayed with the appropriate additive by a plant sprayer, mixed by hand, and then placed into the jar by hand with periodic tamping. The chopped forages were ensiled in 1.5-L anaerobic jars (Weck ${ }^{\circledR}$, Wher-Oflingen, Germany) equipped with a lid that enables gas release only. The experiment had four different triticale lines and three treatments (untreated control and two inoculants) with four replicates (jars). In total, 48 jars were stored at ambient temperature $\left(22-24{ }^{\circ} \mathrm{C}\right)$. Jars were weighed before and after filling to determine the actual amount ensiled. Each jar was filled with about 944, 919, 996, and $906 \mathrm{~g}$ (fresh weight) of chopped forage for C1, $\mathrm{C} 11, \mathrm{C} 13$, and $\mathrm{C} 14$ triticale lines, respectively. The packing densities were $159.4,154.8,166.6$, and $154.3 \mathrm{~kg}$ of dry

Table 1 - Pedigree and origin of triticale lines

\begin{tabular}{lcc}
\hline Pedigree & Origin & Code \\
\hline BANT-2/ RHINO-9//GIRAF/YOGUI-1 & CIMMYT-Mexico & C1 \\
(CMT87.1891-5Y-0M-0RES-17M -1Y-0PAP-4Y-0B) & CIMMYT-Mexico & C11 \\
$\begin{array}{l}\text { SUSI-2 } \\
\text { (CMT86B.386-2Y-1M-5Y-3M-3RES-0B-2Y-0PAP) }\end{array}$ & CIMMYT-Mexico & C13 \\
PASSI-3-2 & & \\
(CMT24476-1M-0Y-0H-0Y-22B-1Y-500B-502RES-0B & CIMMYT-Mexico & \\
CAGUAN-3 & & \\
(CTM86M.2281-5Y-2B-1Y-1B-2RES-0B-1Y-0PAP) & \\
\hline
\end{tabular}


matter $(\mathrm{DM}) / \mathrm{m}^{3}$ for $\mathrm{C} 1, \mathrm{C} 11, \mathrm{C} 13$, and $\mathrm{C} 14$ triticale lines, respectively. Fresh and ensiled forages were sampled for further analysis on day 60 after ensiling.

Chemical analyses of fresh forage and silages were performed in quadruplicate per treatment and presented on a DM basis. The silage $\mathrm{pH}$ was measured directly from the silage juice using a pH meter (Sartorius PB-20, Goettingen, Germany). The DM content of the fresh forage and silages was determined by drying at $60{ }^{\circ} \mathrm{C}$ for $48 \mathrm{~h}$ in a fanassisted oven (Procedure no: 930.15; AOAC, 1990). The dry matter content of the silages was corrected $\left(\mathrm{DM}_{\text {cor }}\right)$ for the loss of volatile substances during drying, using the following equation (Weißbach, 2009): $\left\{\mathrm{DM}_{\mathrm{cor}}=\mathrm{DM}+\right.$ $0.95 \times$ sum of fatty acids $(\mathrm{C} 2-\mathrm{C} 6)+0.08 \times$ lactic acid $+0.77 \times 1,2$ propanediol $+1.00 \times$ other alcohols $(\mathrm{C} 2-\mathrm{C} 6$ including butanediol) $[\mathrm{g} / \mathrm{kg}]\}$. Fresh forage and silages were analyzed for crude protein (CP) and ash according to AOAC (984.13 and 942.05, respectively; 1990). Neutral detergent fiber (NDF) and acid detergent fiber (ADF) were analyzed by using the sodium sulfite addition method without $\alpha$-amylase and expressed with residual ash (Van Soest et al., 1991). Hemicellulose (HC) was calculated as the difference between NDF and ADF. Wet samples stored at $-20^{\circ} \mathrm{C}$ were extracted for $3 \mathrm{~min}$ in a blender in water or in ethyl acetate (1:9) for WSC and fermentation products analysis. The WSC were determined by the phenol sulfuric acid method (Dubois et al., 1956). Lactic acid was determined by a spectrophotometry method (Barker and Summerson, 1941). The volatile fatty acids (VFA) and alcohol concentrations were analyzed using a gas chromatograph with a capillary column (over a temperature range 45 to $230^{\circ} \mathrm{C}$ ). Ammonia-N was determined by using Kjeltech auto analyzer (Gerhardt, Germany) without a digestion step, according to AOAC (ID 941.04, 1990).

Microbiological analyses of fresh forage and silages were performed in quadruplicate (per treatment for each replicate) and presented on fresh and wet silage basis. Microbiological evaluation included enumeration of lactobacilli on pour-plate Rogosa agar (Oxoid CM627, Oxoid, Basingstoke, U.K.), and yeast and mold on spreadplate malt extract agar (Difco, Detroit, MI) acidified with lactic acid to $\mathrm{pH} 4.0$. Plates were incubated for $3 \mathrm{~d}$ at $30^{\circ} \mathrm{C}$. All microbiological data were transformed to $\log _{10}$.

At the end of the ensiling period (day 60), the silages were subjected to an aerobic stability test at room temperature $\left(22{ }^{\circ} \mathrm{C}\right)$, which lasted $5 \mathrm{~d}$, in a "polyethylene terephthalate (P.E.T.) bottle" system developed by Ashbell et al. (1991). The system was constructed from recycled soft drink bottles (polyethylene terephthalate) in two parts: the upper part (1-L) was filled with $250 \mathrm{~g}$ (wet weight) of loosely packed silage, and the lower part with $100 \mathrm{~mL}$ of $20 \% \mathrm{KOH}$. Gas was exchanged through 1-cm holes in the lid of the upper part to the lower part. The $\mathrm{CO}_{2}$ produced during aerobic exposure was absorbed in the base and determined by titration with $1 \mathrm{~N} \mathrm{HCl}$. In addition, silage $\mathrm{pH}$ was measured and yeast and mold analyses were performed as the indicators of aerobic spoilage as well. The $\mathrm{pH}$, yeast, and mold analysis were determined by the previously explained analysis methods. Analyses were carried out on the silage samples after $5 \mathrm{~d}$ of exposure to air.

Rumen degradability characteristics of the silages were measured by the method reported by Mehrez and Ørskov (1977). Air-dried forage samples were ground through a $2.5 \mathrm{~mm}$ screen using a laboratory-type mill. The milled samples $(5 \mathrm{~g} \mathrm{DM})$ were placed in $9 \times 14 \mathrm{~cm}$ Dacron bags (pore size 40-60 $\mu \mathrm{m}$ ), which were inserted into three rumen-cannulated male Merino sheep. The sheep were fed a diet based on wheat grain and sunflower meal plus alfalfa hay. The 48 dacron bags (16 bags/sheep) were incubated in the rumen for $48 \mathrm{~h}$. In the residue after incubation, DM (ID 930.15; AOAC, 1990), OM (ID 942.05; AOAC, 1990), and NDF (Van Soest et al., 1991) were determined.

Production cost of maize (silage) and triticale was calculated based on their total fixed and variable costs. Fixed costs included land rent, permanent labor, and depreciation. Depreciation cost was calculated according to the straight line method. Miscellaneous cost was taken as $1 \%$ and interest on pre-harvest variable cost was taken as $5 \%$ of the total amount of variable costs. The exchange rate used was 1 euro $=3.14$ Turkish lira.

A randomized complete block design with three replicates was used for evaluating the lines. The data obtained from silage quality were analyzed as a completely randomized design with four replications and subjected to analysis of variance by the GLM procedure of SAS (Statistical Analysis System, version 6.0). Differences among means were tested using Tukey's test and significance was declared at $\mathrm{P}<0.05$, whereas trends were discussed at $\mathrm{P}<0.10$, unless stated otherwise.

Statistical model:

$$
\text { Yijl }=\mu+\tau \mathrm{i}+\gamma \mathrm{j}+\tau \gamma \mathrm{ij}+\mathrm{eijl}
$$

in which $\mu=$ overall mean; $\tau i=$ effect of line $i ; \gamma j=$ effect of treatment $\mathrm{j} ; \tau \gamma \mathrm{ij}=$ line $\times$ treatment interaction; and eijl $=$ residual error.

\section{Results}

Among the pre-ensiled triticale lines, forage yield, ear/stalk ratio, and chemical composition were not different $(\mathrm{P}>0.05)$. On the other hand, the differences between plant 
height and hay yield were affected $(\mathrm{P}<0.05)$. Forage yield of triticale lines ranged between 44.28 and $41.61 \mathrm{t} / \mathrm{ha}$ (Table 2). The plant height and the hay yield were lowest $(\mathrm{P}<0.01)$ in lines $\mathrm{C} 13(91.33 \mathrm{~cm})$ and $\mathrm{C} 14(13.86 \mathrm{t} / \mathrm{ha})$, respectively. The epiphytic lactobacilli counts were low in pre-ensiled triticale, each being $<4 \log \mathrm{cfu} / \mathrm{g}$.

All silages were relatively well fermented, but the extent of fermentation differed depending on the LAB+enzyme applications. The volatile corrected DM contents of the untreated and treated silages were 39.16 and 38.75, respectively. The crude protein content of the $\mathrm{LAB}+$ enzyme treated triticale silages tended to be higher $(\mathrm{P}=0.06)$ than that of untreated silage. The use of LAB+enzyme lowered $(\mathrm{P}<0.05)$ the NDF and the least $(\mathrm{P}<0.05) \mathrm{NDF}$ was observed in $\mathrm{C} 14$ silages treated with $\mathrm{LAB}+$ enzyme I. The LAB+enzyme I tended $(\mathrm{P}=0.12)$ to reduce $\mathrm{ADF}$ contents in the silages from $\mathrm{C} 1, \mathrm{C} 11$, and $\mathrm{C} 13$ triticale. No interactions $(\mathrm{P}>0.05)$ were found between the lines and the treatments (Table 4) for fermentation metabolites except for $\mathrm{pH}$ and butyrate $(\mathrm{P}<0.01)$. The $\mathrm{pH}$ values for $\mathrm{C} 1$ and $\mathrm{C} 13$ control silages were greater $(\mathrm{P}<0.01)$ than the other silages. The butyrate for $\mathrm{C} 14$ control silages was greater $(\mathrm{P}<0.01)$ than the other groups. The concentration of lactic and acetic acid of silages ranged from 42.4 to 64.0 and 2.0 to $6.2 \mathrm{~g} / \mathrm{kg} \mathrm{DM}$, respectively (Table 4$)$. The acetate concentration was lower $(\mathrm{P}<0.05)$, whereas the lactate concentration was higher $(\mathrm{P}<0.05)$ in silages treated with $\mathrm{LAB}+$ enzymes when compared with the control. No butyric acid was detected in either $\mathrm{LAB}+$ enzyme treated silage. The concentrations of WSC and the total alcohols were decreased $(\mathrm{P}<0.05)$ by the inclusion of LAB+enzymes. The differences in the ammonia- $\mathrm{N}$ concentrations tended $(\mathrm{P}=0.10)$ to be reduced by LAB+enzymes (Table 4).
After $60 \mathrm{~d}$ of ensiling, lactobacilli counts were increased $(\mathrm{P}<0.05)$ by both $\mathrm{LAB}+$ enzymes applications, whereas yeast counts were not affected $(\mathrm{P}=0.33)$ by treatments (Table 5$)$. However, there were lower amounts of yeast in $\mathrm{C} 13$ line triticale treated with the LAB+enzyme II than the untreated or other treated silages. Regardless of treatments, mold counts were low in all triticale silages, each being $<2$.

The $\mathrm{pH}$ and the release of $\mathrm{CO}_{2}$ were lower $(\mathrm{P}<0.05)$ in the $\mathrm{LAB}+$ enzyme treated silages than the untreated silage. The most significant $(\mathrm{P}<0.05)$ improvement in aerobic stability was seen in $\mathrm{C} 13 \mathrm{LAB}+$ enzyme I treated silage because of the lower activity of yeast than the other silages. There were no obvious effects of line and treatment interactions on yeast $(\mathrm{P}=0.80)$ and mold $(\mathrm{P}=0.46)$ numbers of the triticale silages.

Both LAB+enzymes treatments increased $(\mathrm{P}<0.05)$ the in situ DM or NDF digestibility of triticale silages. In addition, organic matter digestibility (OMD) of triticale silage was greater $(7.04 \% ; \mathrm{P}<0.05)$ after $48 \mathrm{~h}$ in the rumen treated by $\mathrm{LAB}+$ enzymes than in the untreated controls (Table 7). No interactions ( $\mathrm{P}>0.05)$ were observed between the lines and the treatments for any of the digestibility parameters, except for $\mathrm{DM}$ digestibility $(\mathrm{P}<0.01)$. The highest $(\mathrm{P}<0.01) \quad \mathrm{DM}$ digestibility was noted in $\mathrm{C} 1$ $\mathrm{LAB}+$ enzyme I treated silages.

The comparison of production costs for maize (silage) and triticale was calculated based on their green forage yield (Table 8). Green forage yield of maize was substantially different according to production period. While the green forage yield was between 9 and $10 \mathrm{t} / \mathrm{da}$ in April sowning, it dropped to $7 \mathrm{t} / \mathrm{da}$ in June and 5-6 t/da in July as a second crop. In our calculation, the production period was June. Maize and triticale were both produced on the same research

Table 2 - Plant height, forage yield, chemical composition, and epiphytic lactobacilli of fresh triticale lines before ensiling

\begin{tabular}{|c|c|c|c|c|c|c|}
\hline \multirow{2}{*}{ Parameter } & \multicolumn{4}{|c|}{ Line } & \multirow{2}{*}{ SEM } & \multirow{2}{*}{ P-value } \\
\hline & $\mathrm{C} 1$ & $\mathrm{C} 11$ & $\mathrm{C} 13$ & $\mathrm{C} 14$ & & \\
\hline Plant height (cm) & $106.93 \mathrm{a}$ & $106.23 a$ & $91.33 \mathrm{~b}$ & $100.26 \mathrm{a}$ & 2.86 & $<0.01$ \\
\hline Forage yield (t/ha) & 44.28 & 42.77 & 43.21 & 41.61 & 1.89 & 0.79 \\
\hline Hay yield (t/ha) & $15.94 \mathrm{a}$ & $15.52 \mathrm{a}$ & $15.77 \mathrm{a}$ & $13.86 b$ & 0.30 & $<0.01$ \\
\hline Ear/stalk & 0.45 & 0.46 & 0.45 & 0.44 & 0.05 & 0.99 \\
\hline Dry matter (g/kg) & 375.6 & 384.3 & 373.7 & 392.4 & 2.90 & 0.79 \\
\hline $\mathrm{pH}$ & 6.31 & 6.33 & 6.41 & 6.38 & 0.05 & 0.50 \\
\hline NDF (g/kg DM) & 583.8 & 584.4 & 586.0 & 577.8 & 6.20 & 0.80 \\
\hline $\mathrm{ADF}(\mathrm{g} / \mathrm{kg} \mathrm{DM})$ & 370.3 & 370.7 & 373.5 & 375.2 & 8.00 & 0.96 \\
\hline $\mathrm{HC}(\mathrm{g} / \mathrm{kg} \mathrm{DM})$ & 226.4 & 203.5 & 212.5 & 202.6 & 1.40 & 0.39 \\
\hline WSC (g/kg DM) & 109.43 & 108.30 & 106.63 & 110.53 & 2.22 & 0.38 \\
\hline Lactobacilli (log cfu/g DM) & $<2$ & $<2$ & $<2$ & $<2$ & 0.18 & 0.85 \\
\hline
\end{tabular}

SEM - standard error of the mean; DM - dry matter; CP - crude protein; NDF - neutral detergent fiber; ADF - acid detergent fiber; HC - hemicellulose (calculated as the difference between NDF and ADF); WSC - water soluble carbohydrates; log - logarithm of the numbers; cfu - colony-forming units.

Means in the same row with different letters differ significantly $(\mathrm{P}<0.05)$. 
farm of the University. Thus, fixed costs of both were similar. Triticale was grown under dry farming conditions. The unit cost of maize was three times higher than that of triticale under the same farm conditions. In the same farm conditions, the OM degradability of maize was 60\% (Filya, 2004), while the triticale OM degradability was $50 \%$. Therefore, we calculated the cost per OMD in maize and triticale as 28.14 and 14.30 euro/t, respectively.

\section{Discussion}

Agronomic and economic information indicates that winter sown whole crop triticale in farming operation has many advantages. The advantages of triticale for silage in semi-arid climates are that it can grow on winter rains with very high yield and could be grown for a double cropping system (Hogg et al., 2002; Jacobs et al., 2009). Goodquality whole-crop triticale silage can serve as adequate forage for lactating dry cows or beef cattle when the demand for energy is high and the need for protein is low (de Ruiter et al., 2002; Hogg et al., 2002). Stage of maturity is a key determinant of the nutritional quality of triticale. The dough stage is a good time to cut triticale for silage because most of the kernel dry matter (DM) accumulates during this stage (Kennelly and Weinberg, 2003).

In the present study, agronomical traits and production cost of triticale as well as nutritional value of triticale silages were investigated with or without LAB+enzyme. The plant height differed between triticale lines. The highest plant height was found in the $\mathrm{C} 1$ line $(106.93 \mathrm{~cm})$, whereas the lowest $(\mathrm{P}<0.05)$ plant height $(91.3 \mathrm{~cm})$ was observed in the C13 line (Table 2). These findings are supported by Mut et al. (2006). Forage yield of triticale for the present study was higher than the values reported by Kara et al. (2009), Lozano-del Rio et al. (2010), and Kaplan et al. (2015). Hay yield of triticale lines varied between 13.86-15.94 t/ha, with the lowest value in $\mathrm{C} 14$ and the highest value in C1, C13, and C11, respectively (Table 2). Hay yields of the current study were similar to those reported by Delogu et al. (2002) and Santiveri et al. (2004), but higher than the values of Lithourgidis et al. (2006). Such differences in hay yields were mainly due to differences in climate conditions and

Table 3 - Chemical composition of triticale silages and triticale silages treated with inoculants after a 60-day ensiling period

\begin{tabular}{|c|c|c|c|c|c|c|c|c|}
\hline \multicolumn{2}{|c|}{ Factor } & $\mathrm{DM}$ & $\mathrm{DM}_{\text {cor }}$ & $\mathrm{CP}$ & Ash & NDF & ADF & $\mathrm{HC}$ \\
\hline & & \multicolumn{6}{|c|}{ (g/kg DM) } & \\
\hline \multicolumn{9}{|c|}{ Line (L) } \\
\hline \multicolumn{2}{|l|}{$\mathrm{C} 1$} & $38.04 \mathrm{a}$ & $38.87 \mathrm{a}$ & 9.02 & 7.44 & 56.97 & 35.49 & 21.48 \\
\hline \multicolumn{2}{|c|}{ C11 } & $37.94 \mathrm{ab}$ & $38.77 \mathrm{ab}$ & 8.97 & 7.38 & 56.84 & 36.14 & 20.71 \\
\hline \multicolumn{2}{|c|}{ C13 } & $37.67 \mathrm{~b}$ & $38.53 b$ & 9.14 & 7.55 & 57.61 & 35.95 & 21.65 \\
\hline \multicolumn{2}{|c|}{$\mathrm{C} 14$} & $38.38 \mathrm{a}$ & $39.24 a$ & 8.92 & 7.41 & 56.41 & 36.36 & 20.05 \\
\hline \multicolumn{2}{|c|}{ SEM } & 0.21 & 0.22 & 0.16 & 0.12 & 0.38 & 0.4 & 0.5 \\
\hline \multicolumn{9}{|c|}{ Treatment (T) } \\
\hline \multicolumn{2}{|c|}{ Control } & 38.15 & 39.14 & 8.73 & 7.47 & $57.62 \mathrm{a}$ & 36.6 & 21.02 \\
\hline \multicolumn{2}{|c|}{$\mathrm{LAB}+\mathrm{E}$ I } & 37.95 & 38.75 & 9.12 & 7.43 & $56.89 \mathrm{ab}$ & 35.84 & 20.85 \\
\hline \multicolumn{2}{|c|}{$\mathrm{LAB}+\mathrm{E}$ II } & 37.93 & 38.68 & 9.18 & 7.44 & $56.36 \mathrm{~b}$ & 35.5 & 21.04 \\
\hline \multicolumn{2}{|c|}{ SEM } & 0.19 & 0.18 & 0.14 & 0.11 & 0.32 & 0.34 & 0.48 \\
\hline \multicolumn{9}{|c|}{$\mathrm{L} \times \mathrm{T}$} \\
\hline \multirow[t]{3}{*}{$\mathrm{C} 1$} & Control & $392.4 \mathrm{a}$ & $395.1 \mathrm{~cd}$ & 87.4 & 74.2 & $577.0 \mathrm{abc}$ & 356.2 & 220.9 \\
\hline & $\mathrm{LAB}+\mathrm{E} \mathrm{I}$ & $384.3 b$ & $392.1 b c$ & 90.4 & 75.2 & $566.0 \mathrm{bcd}$ & 350.0 & 216.0 \\
\hline & LAB+E II & $383.9 b$ & $388.9 \mathrm{bcd}$ & 92.8 & 73.7 & $566.1 \mathrm{bcd}$ & 358.5 & 207.6 \\
\hline \multirow[t]{3}{*}{$\mathrm{C} 11$} & Control & $381.8 \mathrm{bc}$ & $394.1 b$ & 87.4 & 74.9 & $574.8 \mathrm{abc}$ & 372.8 & 202.1 \\
\hline & $\mathrm{LAB}+\mathrm{E}$ I & $381.1 \mathrm{bcd}$ & $386.9 \mathrm{bcd}$ & 88.8 & 71.6 & $562.9 \mathrm{bcd}$ & 354.5 & 208.3 \\
\hline & $\mathrm{LAB}+\mathrm{E}$ II & $379.6 \mathrm{bcd}$ & $382.1 \mathrm{~d}$ & 93.0 & 75.0 & $567.7 \mathrm{bcd}$ & 356.8 & 210.9 \\
\hline \multirow[t]{3}{*}{$\mathrm{C} 13$} & Control & $379.5 \mathrm{bcd}$ & $383.4 d$ & 89.1 & 74.9 & $577.4 \mathrm{ab}$ & 363.2 & 214.2 \\
\hline & LAB+E 1 & $379.0 \mathrm{bcd}$ & $383.4 d$ & 92.0 & 74.5 & $561.2 \mathrm{~cd}$ & 355.6 & 205.7 \\
\hline & LAB+E II & $375.6 \mathrm{~cd}$ & $389.4 \mathrm{bcd}$ & 93.0 & 77.0 & $589.6 \mathrm{a}$ & 359.9 & 229.7 \\
\hline \multirow[t]{4}{*}{ C14 } & Control & $375.6 \mathrm{~cd}$ & $402.9 \mathrm{a}$ & 85.3 & 74.7 & $575.5 \mathrm{abc}$ & 371.9 & 203.7 \\
\hline & $\mathrm{LAB}+\mathrm{E} \mathrm{I}$ & $374.7 \mathrm{~cd}$ & $387.4 \mathrm{bcd}$ & 93.7 & 75.8 & $564.3 \mathrm{bcd}$ & 360.2 & 204.1 \\
\hline & LAB+E II & $373.7 d$ & $386.9 \mathrm{bcd}$ & 88.7 & 71.7 & $552.4 \mathrm{~d}$ & 358.7 & 193.8 \\
\hline & SEM & 0.13 & 0.16 & 0.16 & 0.12 & 0.32 & 0.43 & 0.56 \\
\hline \multicolumn{2}{|c|}{ Line (L) } & $<0.01$ & $<0.01$ & 0.79 & 0.79 & 0.09 & 0.53 & 0.18 \\
\hline \multicolumn{2}{|c|}{ Treatment (T) } & 0.44 & 0.06 & 0.06 & 0.96 & $<0.01$ & 0.12 & 0.95 \\
\hline \multicolumn{2}{|c|}{$\mathrm{L} \times \mathrm{T}$} & $<0.01$ & $<0.01$ & 0.78 & 0.61 & $<0.01$ & 0.89 & 0.53 \\
\hline
\end{tabular}

DM - dry matter; $\mathrm{DM}_{\text {cor }}$ - dry matter corrected for loss of volatiles; CP - crude protein; NDF - neutral detergent fiber; ADF - acid detergent fiber; HC - hemicellulose (calculated as the difference between NDF and ADF); LAB+E I - Pediococcus acidilactici, Lactobacillus plantarum, and Streptococcus faecium with cellulase, hemicellulase, pentosanase, and amylase; LAB+E II - P. acidilactici, L. plantarum, and amylase; SEM - standard error of the mean.

Means in the same column with different letters differ significantly $(\mathrm{P}<0.05)$. 
different responses of genotypes against different conditions (Kaplan et al., 2015). These differences may also result from higher nutrient accumulation levels of early-spiking plants (Delogu et al., 2002). Ear/stalk ratio was 0.44-0.46, averaging 0.45 (Table 2). Contrary to the result in this study, Nadeau (2007) determined this ratio as 0.85. In this study, we found that the DM content (373.7-392.4 g/ kg fresh matter), and ADF (372.7 $\mathrm{g} / \mathrm{kg} \mathrm{DM})$ values were optimal to ensure maximum quality silage and dry matter intake, whilst protein content was moderate, between 89.1 and $93.6 \mathrm{~g} / \mathrm{kg}$ DM (Table 2), which is characteristic of the dough stage whole-crop triticale (Kennelly and Weinberg, 2003). Available soluble carbohydrates for primary fermentation were sufficient (106.6-110.5 g/kg DM; Table 2) in all triticale lines (McDonald et al., 1991). Nadeau (2007) reported that whole crop triticale harvested in the early dough stage of maturity contained $350 \mathrm{~g} / \mathrm{kg} \mathrm{DM}, 770.0 \mathrm{~g} / \mathrm{kg}$ $\mathrm{CP}$, and $334.3 \mathrm{~g} / \mathrm{kg}$ ADF compared with $292 \mathrm{~g} / \mathrm{kg} \mathrm{DM}$, $103.1 \mathrm{~g} / \mathrm{kg} \mathrm{CP}$, and $229.9 \mathrm{~g} / \mathrm{kg}$ ADF for triticale silage harvested in the early milk stage of maturity.

The CP content of the untreated $(87.3 \mathrm{~g} / \mathrm{kg} \mathrm{DM})$ triticale silages was slightly affected by the storage period in relation to the fresh material $(92.1 \mathrm{~g} / \mathrm{kg}$ DM; Tables 2 and 3). The CP content of untreated silage was lower than that of both fresh forage $(5.21 \%)$ and $\mathrm{LAB}+$ enzyme treated $(4.7 \%)$ silages. This indicates a controlled fermentation with less proteolysis in $\mathrm{LAB}+$ enzyme treated silages than in untreated silages. Similar results were also reported by Jacobs et al. (2009), who demonstrated that LAB+enzyme increased the $\mathrm{CP}$ content of the early dough triticale silage relative to either fresh forage or untreated control silage. The ammonia- $\mathrm{N}$ in silages shows the degree of protein degradation. Extensive proteolysis adversely affects the utilization of nitrogen by ruminants (McDonald et al., 1991). It was observed that ammonia-N was lower in LAB+enzyme treated silages relative to untreated silage. On the other hand, the level of ammonia-N formation in all silages in the present experiment was below the threshold level of $80 \mathrm{~g} / \mathrm{kg}$ of total nitrogen for good quality silages (McDonald et al., 1991). The LAB+enzymes treatment influenced $(\mathrm{P}<0.05)$ the fibrous fractions of the triticale silages (Table 3). Decomposition of cell walls in enzyme treated silages with or without LAB is supposedly a result of hydrolysis of hemicellulose (Kung et al., 2003), which

Table 4 - Fermentation metabolites of triticale silages and triticale silages treated with inoculants after a 60 -day ensiling period

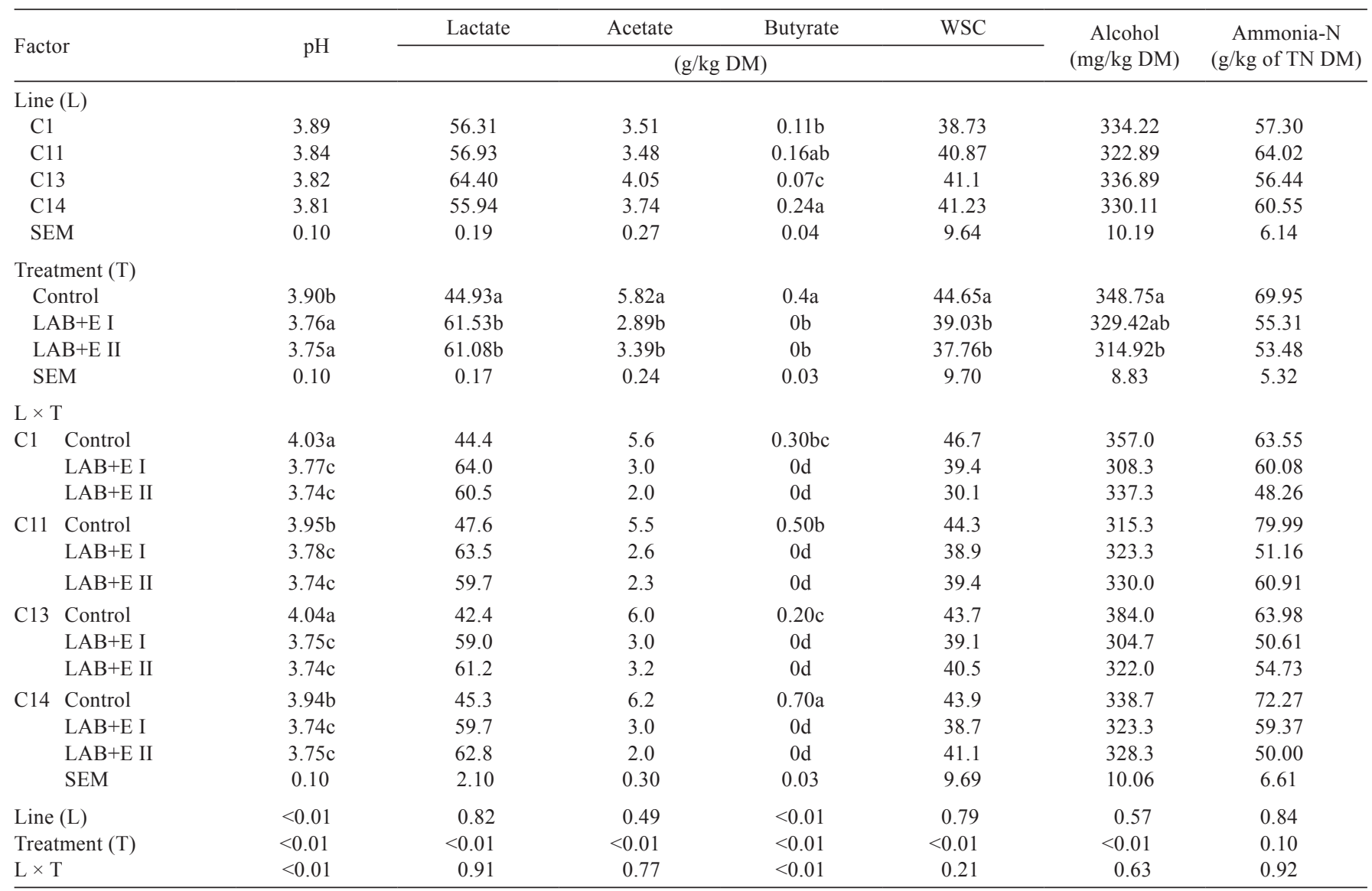

WSC - water soluble carbohydrates; DM - dry matter; TN - total nitrogen; LAB+E I - Pediococcus acidilactici, Lactobacillus plantarum, and Streptococcus faecium with cellulase, hemicellulase, pentosanase, and amylase; LAB+E II - P. acidilactici, L. plantarum, and amylase; SEM - standard error of the mean.

Means in the same column with different letters differ significantly $(\mathrm{P}<0.05)$. 
can improve the availability of energy for fermentation in the silo and in the rumen proven by the increase in OM digestibility (7.2\%; Table 7 ) in our LAB+enzyme treated silages. Ozduven et al. (2010) and Demirel et al. (2013) similarly reported that LAB with enzymes disturbed cell membranes and released soluble cell contents in triticale and barley/triticale silages. However, a study (Zahiroddini et al., 2004) with barley silage yielded conflicting results. In that study, it was reported that enzyme with LAB or alone increased the silage NDF and ADF content, showing that the enzyme-mediated release of soluble sugars from cell wall was lower (Zahiroddini et al., 2004).

In this case, using a $\mathrm{LAB}+$ enzyme mixture promoted a more satisfactory fermentation, which improved conservation of dry matter, reduced solubilization of nitrogen, and gave greater stability to triticale silages (Tables 3-6). Resulting from lactobacilli activity, LAB+enzyme treated silages contained significant levels of lactic acid. The production of volatile fatty acids, other than

Table 5 - Microbiological composition of triticale silages and triticale silages treated with inoculants after a 60-day ensiling period

\begin{tabular}{|c|c|c|c|c|}
\hline \multicolumn{2}{|c|}{ Factor } & Lactobacilli & Yeasts & Molds \\
\hline & & \multicolumn{3}{|c|}{$(\log \mathrm{cfu} / \mathrm{g} \mathrm{DM})$} \\
\hline \multicolumn{5}{|c|}{ Line (L) } \\
\hline \multicolumn{2}{|c|}{$\mathrm{C} 1$} & 6.56 & 2.37 & 1.71 \\
\hline \multicolumn{2}{|c|}{$\mathrm{C} 11$} & 6.84 & 2.43 & 1.37 \\
\hline \multicolumn{2}{|c|}{$\mathrm{C} 13$} & 7.00 & 2.00 & 1.51 \\
\hline \multicolumn{2}{|c|}{ C14 } & 7.05 & 1.98 & 1.48 \\
\hline \multicolumn{2}{|c|}{ SEM } & 0.43 & 0.25 & 0.20 \\
\hline \multicolumn{5}{|c|}{ Treatment (T) } \\
\hline \multicolumn{2}{|c|}{ Control } & $5.71 b$ & 2.45 & 1.70 \\
\hline \multicolumn{2}{|c|}{$\mathrm{LAB}+\mathrm{E}$ I } & $7.46 \mathrm{a}$ & 2.10 & 1.36 \\
\hline \multicolumn{2}{|c|}{$\mathrm{LAB}+\mathrm{E}$ II } & $7.42 \mathrm{a}$ & 2.05 & 1.49 \\
\hline \multicolumn{2}{|c|}{ SEM } & 0.37 & 0.22 & 0.18 \\
\hline \multicolumn{5}{|c|}{$\mathrm{L} \times \mathrm{T}$} \\
\hline \multirow[t]{3}{*}{$\mathrm{C} 1$} & Control & $5.32 \mathrm{c}$ & 2.71 & 2.26 \\
\hline & LAB+E I & $7.15 \mathrm{abc}$ & 1.67 & $<2$ \\
\hline & $\mathrm{LAB}+\mathrm{E}$ II & $7.21 \mathrm{ab}$ & 2.74 & $<2$ \\
\hline \multirow[t]{3}{*}{ C11 } & Control & $5.71 b c$ & 2.65 & $<1$ \\
\hline & $\mathrm{LAB}+\mathrm{E} \mathrm{I}$ & $7.39 \mathrm{ab}$ & 2.49 & $<2$ \\
\hline & $\mathrm{LAB}+\mathrm{E}$ II & $7.42 \mathrm{ab}$ & 2.16 & $<2$ \\
\hline \multirow[t]{3}{*}{$\mathrm{C} 13$} & Control & $6.00 \mathrm{abc}$ & 1.93 & $<2$ \\
\hline & LAB+E I & $7.50 \mathrm{ab}$ & 2.65 & $<2$ \\
\hline & $\mathrm{LAB}+\mathrm{E}$ II & $7.51 \mathrm{ab}$ & 1.43 & $<2$ \\
\hline \multirow[t]{4}{*}{ C14 } & Control & $5.81 b c$ & 2.49 & $<2$ \\
\hline & $\mathrm{LAB}+\mathrm{E} \mathrm{I}$ & $7.80 \mathrm{a}$ & 1.57 & $<2$ \\
\hline & LAB+E II & $7.53 \mathrm{ab}$ & 1.87 & $<2$ \\
\hline & SEM & 0.31 & 0.23 & 0.20 \\
\hline \multicolumn{2}{|c|}{ Line $(\mathrm{L})$} & 0.77 & 0.38 & 0.69 \\
\hline \multicolumn{2}{|c|}{ Treatment (T) } & $<0.01$ & 0.33 & 0.40 \\
\hline \multicolumn{2}{|c|}{$\mathrm{L} \times \mathrm{T}$} & $<0.01$ & 0.15 & 0.45 \\
\hline
\end{tabular}

$\log$ - logarithm of the numbers; cfu - colony-forming units; DM - dry matter; LAB+E I Pediococcus acidilactici, Lactobacillus plantarum, and Streptococcus faecium with cellulase, hemicellulase, pentosanase, and amylase; LAB+E II - P. acidilactici, L. plantarum, and amylase; SEM - standard error of the mean.

Means in the same column with different letters differ significantly $(\mathrm{P}<0.05)$. acetic, was very small and no butyric acid was detected in LAB+enzyme treated silages. The disappearance of soluble carbohydrates (WSC) was measured in concert with the process of acidification in treated silages. These results are in accordance with those with cereal silages (Zahiroddini et al., 2004; Sucu and Filya, 2006; Nadeau, 2007; Xie et al., 2012) and can be related to better preservation.

Temperature, DM and WSC content, microbial population, and concentration of fermentation products in interaction with $\mathrm{pH}$ have the greatest direct effects on aerobic stability. The consumption of sugar and acids raises the $\mathrm{pH}$ and accelerates the process of aerobic instability with high dry matter losses after opening the silo (McDonald et al., 1991). In the current study, after exposing the silages for five days, the number of yeasts was increased when compared with the number of yeasts that are not exposed to air (Table 6). As a result, the $\mathrm{pH}$ increased (4.3) during air exposure compared with final silage $\mathrm{pH}$ (3.9). This suggests that, regardless of using additives, silages sooner or later

Table 6 - Results of aerobic stability test ( 5 d) of triticale silages and triticale silages treated with inoculants after a 60-day ensiling period

\begin{tabular}{|c|c|c|c|c|c|}
\hline \multicolumn{2}{|c|}{ Treatment } & $\mathrm{pH}$ & $\begin{array}{c}\mathrm{CO}_{2} \\
(\mathrm{~g} / \mathrm{kg} \mathrm{DM})\end{array}$ & $\begin{array}{c}\text { Yeasts } \\
(\log \mathrm{cfu} / \mathrm{g} \\
\mathrm{DM})\end{array}$ & $\begin{array}{c}\text { Molds } \\
(\log \mathrm{cfu} / \mathrm{g} \\
\mathrm{DM})\end{array}$ \\
\hline \multicolumn{6}{|c|}{ Line (L) } \\
\hline \multicolumn{2}{|c|}{ C1 } & 4.25 & 4.82 & $5.67 \mathrm{a}$ & 2.28 \\
\hline \multicolumn{2}{|c|}{ C11 } & 4.31 & 5.27 & $4.69 \mathrm{ab}$ & 2.15 \\
\hline \multicolumn{2}{|c|}{ C13 } & 4.26 & 5.23 & $4.20 \mathrm{~b}$ & 2.20 \\
\hline \multicolumn{2}{|c|}{$\mathrm{C} 14$} & 4.24 & 5.25 & $4.10 \mathrm{~b}$ & 2.18 \\
\hline \multicolumn{2}{|c|}{ SEM } & 0.03 & 0.21 & 0.36 & 0.06 \\
\hline \multicolumn{6}{|c|}{ Treatment $(\mathrm{T})$} \\
\hline \multicolumn{2}{|c|}{ Control } & $4.50 \mathrm{a}$ & 5.96 & $5.82 \mathrm{a}$ & 2.26 \\
\hline \multicolumn{2}{|c|}{$\mathrm{LAB}+\mathrm{E} \mathrm{I}$} & $4.20 \mathrm{~b}$ & 4.99 & $4.53 b$ & 2.14 \\
\hline \multicolumn{2}{|c|}{$\mathrm{LAB}+\mathrm{E}$ II } & $4.11 b$ & 4.48 & $4.63 b$ & 2.19 \\
\hline \multicolumn{2}{|c|}{ SEM } & 0.03 & 0.18 & 0.30 & 0.06 \\
\hline \multicolumn{6}{|c|}{$\mathrm{L} \times \mathrm{T}$} \\
\hline & Control & 4.48 & 5.60 & 5.73 & 2.46 \\
\hline & $\mathrm{LAB}+\mathrm{E} \mathrm{I}$ & 4.13 & 4.82 & 5.55 & 2.19 \\
\hline & $\mathrm{LAB}+\mathrm{E}$ II & 4.13 & 4.05 & 5.73 & 2.29 \\
\hline \multirow[t]{3}{*}{$\mathrm{C} 11$} & Control & 4.51 & 6.00 & 4.62 & 2.04 \\
\hline & LAB+E I & 4.25 & 5.18 & 5.92 & 2.13 \\
\hline & $\mathrm{LAB}+\mathrm{E}$ II & 4.17 & 4.63 & 4.34 & 2.27 \\
\hline \multirow[t]{3}{*}{ C13 } & Control & 4.55 & 6.16 & 4.72 & 2.37 \\
\hline & $\mathrm{LAB}+\mathrm{E} \mathrm{I}$ & 4.11 & 5.06 & 3.41 & 2.23 \\
\hline & $\mathrm{LAB}+\mathrm{E}$ II & 4.21 & 4.46 & 4.46 & 2.19 \\
\hline \multirow[t]{4}{*}{ C14 } & Control & 4.49 & 6.07 & 4.23 & 2.27 \\
\hline & LAB+E I & 4.23 & 4.88 & 4.05 & 2.13 \\
\hline & $\mathrm{LAB}+\mathrm{E}$ II & 4.01 & 4.79 & 4.02 & 2.03 \\
\hline & SEM & 0.03 & 0.22 & 0.36 & 0.06 \\
\hline \multicolumn{2}{|c|}{ Line (L) } & 0.46 & 0.47 & $<0.01$ & 0.53 \\
\hline \multicolumn{2}{|c|}{ Treatment (T) } & $<0.01$ & $<0.01$ & 0.02 & 0.33 \\
\hline \multicolumn{2}{|c|}{$\mathrm{L} \times \mathrm{T}$} & 0.36 & 0.98 & 0.81 & 0.46 \\
\hline
\end{tabular}

DM - dry matter; log - logarithm of the numbers; cfu - colony-forming units; $\mathrm{LAB}+\mathrm{E}$ I - Pediococcus acidilactici, Lactobacillus plantarum, and Streptococcus faecium with cellulase, hemicellulase, pentosanase, and amylase; LAB+E II - P. acidilactici, L. plantarum, and amylase;SEM - standard error of the mean.

Means in the same column with different letters differ significantly $(\mathrm{P}<0.05)$. 
deteriorate. In this study, using $\mathrm{LAB}+$ enzymes helped to reduce the negative signs of aerobiosis in triticale silages proven by the decrease $(\mathrm{P}<0.05)$ in $\mathrm{pH}, \mathrm{CO}_{2}$ production, and the number of yeasts in comparison with untreated silage. Addah et al. (2011) similarly demonstrated the same trend for barley silages. However, in some cases, the addition of LAB with or without enzymes adversely affected aerobic stability of triticale (Ozduven et al., 2010) or other cereal (Sucu and Filya, 2006; Xie et al., 2012) silages.

In the current study, LAB+enzymes inclusion increased $(\mathrm{P}<0.05)$ the amount of degradable $\mathrm{OM}$ as well as the degradable DM and NDF in the rumen (Table 7). This indicated that the LAB+enzymes complement caused enough amount of fiber breakdown due to the adequate application rate $\left(1.5 \times 10^{5}\right)$. These findings agree with other authors (Sucu and Filya, 2006; Ozduven et al., 2010) who demonstrated that $\mathrm{LAB}$ inoculation with or without enzymes increased the DM and NDF digestibilities of cereal silages. However, the lack of an effect of additives on degradable

Table 7 - In situ $48 \mathrm{~h}$ organic matter, dry matter, and fiber digestibility (OMD, DMD, and NDFD) of triticale silages and triticale silages treated with inoculants after a 60-day ensiling period

\begin{tabular}{|c|c|c|c|c|}
\hline \multicolumn{2}{|c|}{ Factor } & OMD & DMD & NDFD \\
\hline & & & $(\mathrm{g} / \mathrm{kg})$ & \\
\hline \multicolumn{5}{|c|}{ Line $(\mathrm{L})$} \\
\hline \multicolumn{2}{|c|}{$\mathrm{C} 1$} & 500.3 & 484.7 & 357.2 \\
\hline \multicolumn{2}{|c|}{ C11 } & 503.6 & 489.5 & 359.0 \\
\hline \multicolumn{2}{|c|}{ C13 } & 496.7 & 484.9 & 370.2 \\
\hline \multicolumn{2}{|c|}{$\mathrm{C} 14$} & 500.8 & 483.9 & 364.8 \\
\hline \multicolumn{2}{|c|}{ SEM } & 0.43 & 0.50 & 0.50 \\
\hline \multicolumn{5}{|c|}{ Treatment $(\mathrm{T})$} \\
\hline \multicolumn{2}{|c|}{ Control } & $477.2 \mathrm{~b}$ & $473.9 b$ & $354.5 b$ \\
\hline \multicolumn{2}{|c|}{$\mathrm{LAB}+\mathrm{E} \mathrm{I}$} & $510.7 \mathrm{a}$ & $495.3 \mathrm{a}$ & $364.5 \mathrm{a}$ \\
\hline \multicolumn{2}{|c|}{$\mathrm{LAB}+\mathrm{E}$ II } & $513.0 \mathrm{a}$ & $488.1 \mathrm{a}$ & $369.8 \mathrm{a}$ \\
\hline \multicolumn{2}{|c|}{ SEM } & 0.37 & 0.43 & 0.43 \\
\hline \multicolumn{5}{|c|}{$\mathrm{L} \times \mathrm{T}$} \\
\hline & Control & 487.3 & 477.9abc & 345.0 \\
\hline & $\mathrm{LAB}+\mathrm{E} \mathrm{I}$ & 496.5 & $498.9 \mathrm{a}$ & 357.8 \\
\hline & $\mathrm{LAB}+\mathrm{E}$ II & 516.3 & $477.2 \mathrm{abc}$ & 368.9 \\
\hline \multirow[t]{3}{*}{$\mathrm{C} 11$} & Control & 481.7 & $477.5 \mathrm{abc}$ & 356.9 \\
\hline & $\mathrm{LAB}+\mathrm{E} \mathrm{I}$ & 516.9 & $497.8 \mathrm{ab}$ & 349.6 \\
\hline & $\mathrm{LAB}+\mathrm{E}$ II & 512.3 & 493.3abc & 370.5 \\
\hline \multirow[t]{3}{*}{$\mathrm{C} 13$} & Control & 460.0 & $469.1 \mathrm{c}$ & 361.3 \\
\hline & $\mathrm{LAB}+\mathrm{E} \mathrm{I}$ & 517.6 & $495.6 \mathrm{abc}$ & 369.4 \\
\hline & $\mathrm{LAB}+\mathrm{E}$ II & 512.6 & $490.0 \mathrm{abc}$ & 379.8 \\
\hline \multirow[t]{4}{*}{ C14 } & Control & 479.7 & $470.9 b c$ & 355.0 \\
\hline & $\mathrm{LAB}+\mathrm{E} \mathrm{I}$ & 511.8 & 488.9abc & 379.3 \\
\hline & $\mathrm{LAB}+\mathrm{E}$ II & 510.9 & 491.7abc & 360.2 \\
\hline & SEM & 0.53 & 0.37 & 0.48 \\
\hline \multicolumn{2}{|c|}{ Line (L) } & 0.87 & 0.63 & 0.24 \\
\hline \multicolumn{2}{|c|}{ Treatment (T) } & $<0.01$ & $<0.01$ & $<0.01$ \\
\hline \multicolumn{2}{|c|}{$\mathrm{L} \times \mathrm{T}$} & 0.84 & $<0.01$ & 0.30 \\
\hline
\end{tabular}

LAB+E I - Pediococcus acidilactici, Lactobacillus plantarum, and Streptococcus faecium with cellulase, hemicellulase, pentosanase, and amylase; LAB+E II - P. acidilactici, L. plantarum, and amylase; SEM - standard error of the mean. Means in the same column with different letters differ significantly $(\mathrm{P}<0.05)$
DM and NDF in the rumen was reported by Zahiroddini et al., (2004). These authors demonstrated that there was no impact of using LAB $\left(1.25 \times 10^{5}\right)$ with cellulolytic and amylolytic enzymes on effective degradability of DM and NDF of whole crop barley silages.

We found that winter sown triticale has the potential to produce significantly higher forage and grain yields compared with winter wheat (10.4-13.0 t/ha; Keady, 2005; Walsh et al., 2008) and might have the potential to reduce unit production costs of forage when compared with corn as a silage. Likewise, Hackett et al. (2012) obtained the same findings with winter sown triticale under Irish conditions. They also stated that triticale has greater disease resistance than wheat and is also thought to be more suited than wheat to lighter and more marginal soils and to take-all prone sites (Hackett et al., 2012). According to Lozano-del Rio et al. (2004), the high forage biomass production and forage quality of triticale increase animal performance, reduce feeding costs, and result in increased return to farmers. In Alberta (Canada), feeding research with triticale, barley, and corn suggested that swath-grazing triticale could reduce winter feeding costs by over $\$ 100$ per cow compared with wintering cows for 100 days in a corral. Savings were lower for swath-grazing barley (\$89) due to lower yields,

Table 8 - Production cost of maize (silage) and triticale

\begin{tabular}{|c|c|c|c|}
\hline & Unit & Maize & Triticale \\
\hline Production area & ha & 9 & 58 \\
\hline \multicolumn{4}{|l|}{ A - Fixed production costs } \\
\hline Land rent & euro/ha & $2,388.54$ & $2,388.54$ \\
\hline Permanent labor & euro & $12,184.06$ & $12,184.06$ \\
\hline Depreciation & euro & $7,643.31$ & $7,643.31$ \\
\hline Subtotal fixed cost & & $20,066.23$ & $20,066.23$ \\
\hline \multicolumn{4}{|l|}{ B - Variable costs } \\
\hline Seed & euro & $1,019.11$ & $7,536.31$ \\
\hline Fertilizer & euro & $2,420.38$ & $6,753.12$ \\
\hline Pesticides & euro & 350.32 & $2,898.15$ \\
\hline Irrigation water & euro & $1,003.18$ & 0.00 \\
\hline Fuel & euro & $4,777.07$ & $5,606.05$ \\
\hline Labor & euro & $6,369.43$ & $10,796.50$ \\
\hline Transport & euro & 159.24 & 159.24 \\
\hline $\begin{array}{l}\text { Miscellaneous ( } 1 \% \\
\text { of variable costs) }\end{array}$ & euro & 160.99 & 337.49 \\
\hline $\begin{array}{l}\text { Interest on pre-harvest } \\
\text { variable cost }(5 \%)\end{array}$ & euro & 812.99 & $1,704.34$ \\
\hline Subtotal variable cost & euro & $17,072.70$ & $35,791.20$ \\
\hline $\mathrm{C}-(\mathrm{A}+\mathrm{B})$ total production costs & euro & $37,138.93$ & $55,857.43$ \\
\hline D - Co-product return & euro & $18,691.56$ & $20,236.62$ \\
\hline Yield (green forage) & $\mathrm{t} / \mathrm{ha}$ & 72.85 & 42.96 \\
\hline E - Total production & $\mathrm{t} / \mathrm{ha}$ & 655.65 & 2.491 .68 \\
\hline OMD yield & $\mathrm{t} / \mathrm{ha}$ & 38.46 & 18.26 \\
\hline Unit cost & euro/t & 56.64 & 22.42 \\
\hline Price & euro/t & 54.14 & 19.10 \\
\hline Unit cost of OMD (C-D/E) & euro/t & 28.14 & 14.30 \\
\hline
\end{tabular}

OMD - organic matter digestibility. 
and for corn (\$83) due to higher input costs. Saade (1995) found that the cost of production of triticale was lower than that of durum and bread wheat, and incorporating $20 \%$ triticale in feed concentrates for ruminants would result in 3.6 Tunisian dinar cost savings per ton of concentrate in Tunisian conditions.

\section{Conclusions}

Triticale improves the profitability of animal production systems. Inoculation of triticale with lactic acid bacteria and enzymes before ensiling improves the quality of the resulting silage. Several interacting factors are involved, including the preservation of more forage protein, the improvement of organic matter digestion in the rumen, and possible probiotic effects of inoculant bacteria and enzymes. These all are linked to increased production response in animals.

\section{Acknowledgments}

The authors would like to thank Köksal Yağdı for providing the triticale lines. Thank to Agricultural Teaching and Research Center for their aid in gathering economic information and finally to Sertaç Dokuzlu for their useful comments on the economic analysis.

\section{References}

Addah, W.; Baah, J.; Okine, E. and McAllister, T. 2011. Comparison of the fermentation characteristics, aerobic stability and nutritive value of barley and corn silages ensiled with or without a mixed bacterial inoculant. Canadian Journal of Animal Science 91:133-146.

Adesogan, A. T. 2005. Improving forage quality and animal performance with fibrolytic enzymes. p.91-109. In: Florida Ruminant Nutrition Symposium, Gainesville, FL.

Ashbell, G.; Weinberg, Z. G.; Azrieli, A.; Hen, Y. and Horev, B. 1991. A simple system to study the aerobic deterioration of lactic acid in biological material. Canadian Agricultural Engineering 34:171-175.

AOAC - Association of Official Analytical Chemists. 1990. Official methods of analysis. 15th ed. AOAC, Arlington, VA.

Barker, S. B. and Summerson, W. H. 1941. The colorimetric determination of lactic acid in biological material. Journal of Biological Chemistry 138:535-554.

Delogu, G.; Faecini, N.; Faccioli, P.; Reggiani, F.; Lendini, M.; Berardo, N. and Odoardi, M. 2002. Dry matter yield and quality evaluation at two phenological stages of forage triticale grown in the Po Valley and Sardinia, Italy. Field Crops Research 74:207-215.

Demirel, G.; Pekel, A. Y.; Ekiz, B.; Biricik, H.; Kocabağli, N. and Alp, M. 2013. The effects of barley/triticale silage on performance, carcass characteristics, and meat quality of lambs. Turkish Journal of Veterinary and Animal Sciences 37:727-733.

de Ruiter, J. M.; Hanson, R.; Hay, A. S.; Armstrong, K. W. and Harrison-Kirk, R. D. 2002. Whole-crop cereals for grazing and silage: balancing quality and quantity. Proceedings of the New Zealand Grassland Association 64:181-189.

Dubois, M.; Gilles, K. A.; Hamilton, J. K.; Rebers, P. A. and Smith, F. 1956. Colorimetric method for determination of sugars and related substances. Analytical Chemistry 28:350-356.

Filya, I. 2004. Nutritive value and aerobic stability of whole crop maize silage harvested at four stages of maturity. Animal Feed Science and Technology 116:141-150.

Hackett, R.; Prior, P. and Tiernan, P. 2012. Agronomy of triticale under Irish conditions. Teagasc Project, Project Number: 5376, Project Dates: Jan 2005-Dec 2007. Available at: <http://www.teagasc.ie/ publications/2007/1543/Agronomy-of-triticale_5376.pdf $>$. Accessed on: Dec. 19, 2015

Hogg, D.; de Ruiter, J. M. and Hanson, R. 2002. Future forages for South Island dairying. Proceedings of SIDE 2002, Invercargill 174-187.

Jacobs, J. L.; Hill, J. and Jenkin, T. 2009. Effect of stage of growth and silage additives on whole crop cereal silage nutritive and fermentation characteristics. Animal Production Science 49:595-607.

Kaplan, M.; Y1lmaz, M. F. and Kara, R. 2015. Variation in hay yield and quality of new triticale lines. Turkish Journal of Agricultural and Natural Sciences 21:50-60

Kara, B.; Ayhan, V.; Akman, Z. and Adiyaman, E. 2009. Determination of silage quality, herbage and hay yield of different triticale cultivars. Asian Journal of Animal and Veterinary Advances 4:167-171.

Keady, T. W. J. 2005. Ensiled maize and whole crop wheat forages for beef and dairy cattle: effects on animal performance. p.65-82. In: Proceedings of the 14th International Silage Conference. Park, R. S. and Stronge, M. D., eds. Belfast, Ireland.

Kennelly, J. J. and Weinberg, Z. G. 2003. Small grain silage. p.749-779. In: Silage science and technology. Buxton, D. R.; Muck, R. E. and Morrison, J. H., eds. American Society of Agronomy, Crop Science Society of America, Soil Science of America, Madison, WI.

Kung, L.-Jr, Stokes, M. R. and Lin, C. J. 2003. Silage additives. p.305-360. In: Silage science and technology. Buxton, D. R.; Muck, R. E. and Morrison, J. H., eds. American Society of Agronomy, Crop Science Society of America, Soil Science of America, Madison, WI.

Lithourgidis, A. S.; Vasilakoglou, I. B.; Dhima, K. V.; Dordas, C. A. and Yiakoulaki, M. D. 2006. Forage yield and quality of common vetch mixtures with oat and triticale in two seeding ratios. Field Crops Research 99:106-113.

Lozano-del Rio, A. J.; Lozano-Cavazos, C. J.; Ibarra-Jimenez, L.; de la Cruz-Lâzaro, E.; Colin-Rico, M.; Zamora-Villa, V. M.; Mergoum, M.; Pfeiffer, W. H. and Ammar, K. 2010. Registration of 'TCLF-AN-105' Triticale. Journal of Plant Registrations 4:127-130.

Lozano-del Rio, A. J.; Sierra, A. H.; Iñiguez, G. R. and Hinojosa, M. B. 2004. Triticale in Mexico. p.123-131. In: Triticale improvement and production. FAO Plant production and protection paper. Mergoum, M. and Gomez-Macpherson, H., eds. UN-FAO, Rome.

McDonald, P.; Henderson, A. R. and Heron, S. J. E. 1991. The biochemistry of silage. 2nd ed. Chalcombe Publications, Abersytwyth, UK

Mut, Z.; Ayan, I. and Mut, H. 2006. Evaluation of forage yield and quality at two phenological stages of triticale genotypes and other cereals grown under rainfed conditions. Bangladesh Journal of Botany 35:45-53.

Myer, R. O. and Lozano del Rio, A. J. 2004. Triticale as animal feed. p.49-59. In: Triticale improvement and production. Mergoum, M. and Gomez-Macpherson, H., eds. UN-FAO, Rome. 
Nadeau, E. 2007. Effects of plant species, stage of maturity and additive on the feeding value of whole-crop cereal silage. Journal of the Science of Food and Agriculture 87:789-801.

Mehrez, A. Z. and Ørskov, E. R. 1977. A study of artificial fibre bag technique for determining the digestibility of feeds in the rumen. Journal of Agricultural Science 88:645-650.

Ozduven, M. L.; Onal, Z. K. and Koc, F. 2010. The effects of bacterial inoculants and/or enzymes on the fermentation, aerobic stability and in vitro dry and organic matter digestibility characteristics of triticale silage. Journal of the Faculty of Veterinary Medicine, University of Kafkas 16:751-756.

Saade, M. E. 1995. Triticale production and utilization in Tunisia: Constraints and prospects, CIMMYT Institutional Multimedia Publications, Economics, Working Paper 95 - 04, Mexico.

Santiveri, F.; Conxita, R. and Ignacio, R. 2004. Growth and yield responses of spring and winter triticale cultivated under Mediterranean conditions. European Journal of Agronomy 20:281-292.

Steenwerth, K. L.; Hodson, A. K.; Bloom, A. J.; Carter, M. R.; Cattaneo, A.; Chartres, C. J.; Hatfield, J. L.; Henry, K.; Hopmans, J. W.; Horwath, W. R.; Jenkins, B. M.; Kebreab, E.; Leemans, R.; Lipper, L.; Lubell, M. N.; Msangi, S.; Prabhu, R.; Reynolds, M. P.; Solis, S. S.; Sischo, W. M.; Springborn, M.; Tittonell, P.; Wheeler, S. M.; Vermeulen, S. J.; Wollenberg, E. K.; Jarvis, L. S. and Jackson, L. E. 2014. Climate-smart agriculture global research agenda: scientific basis for action. Agriculture and Food Security 3:11.
Sucu, E. and Filya, I. 2006. The effects of bacterial inoculants on the fermentation, aerobic stability and rumen degradability characteristics of wheat silages. Turkish Journal of Veterinary and Animal Sciences 30:187-193.

Van Soest, P. J.; Robertson, J. B. and Lewis, B. A. 1991. Methods for dietary fiber, neutral detergent fiber, and nonstarch polysaccharides in relation to animal nutrition. Journal of Dairy Science 74:3583-3597.

Xie, Z. L.; Zhang, T. F.; Chen, X. Z.; Li, G. D. and Zhang, J. G. 2012. The changes in yields and nutritive composition of whole crop wheat (Triticum aestivum L.) during maturation and silage quality of whole crop wheat. Asian Australasian Journal of Animal Sciences 25:1374-1380.

Zahiroddini, H.; Baah, J.; Absalom, W. and McAllister, T. A. 2004. Effect of an inoculant and hydrolytic enzymes on fermentation and nutritive value of whole crop barley silage. Animal Feed Science and Technology 117:317-330.

Walsh, K.; O'Kiely, P.; Moloney, A. P. and Boland, T. M. 2008. Intake, digestibility, rumen fermentation and performance of beef cattle fed diets based on whole-crop wheat or barley harvested at two cutting heights relative to maize silage or ad libitum concentrates. Animal Feed Science and Technology 144:257-278.

Weißbach, F. 2009. Correction of dry matter content of silages used as substrate for biogas production. p.483-484. In: Proceedings of the 15th International Silage Conference, Madison, WI. 